\title{
Ethnicity in Kenyan Universities
}

\author{
Simon Thuranira Taaliu \\ School of Education and Social Sciences, University of Embu, Embu, Kenya \\ Email: thuranira.simon@embuni.ac.ke
}

How to cite this paper: Taaliu, S. T. (2017). Ethnicity in Kenyan Universities. Open Journal of Leadership, 6, 21-33.

https://doi.org/10.4236/oj1.2017.62002

Received: April 11, 2017

Accepted: June 5, 2017

Published: June 8, 2017

Copyright $\odot 2017$ by author and Scientific Research Publishing Inc. This work is licensed under the Creative Commons Attribution International License (CC BY 4.0).

http://creativecommons.org/licenses/by/4.0/

\begin{abstract}
In Kenya, ethnicity has been one of the social problems since independence. It cuts across all sectors of the economy including education. Ethnicity is witnessed in forms of recruitment, promotion, transfer and deployment of lecturers and other non-teaching members of staff. In the universities there is ethnic consideration in recruitment of Chairs of the Council, Vice Chancellors and their Deputies and other top leaders. Politicians in many cases have tried to influence appointments of the top leaderships of public universities. The public universities have more lecturers and the non-teaching staff from the local ethnic group. Ethnicity has also impacted university students as well, especially when electing their student leaders. This paper examines the causes of ethnicity and some of the recommendations on how to tackle the vice. Some of the recommendations include empowering the National Cohesion and Integration Commission (NCIC) and vetting of Vice Chancellors and Council members.
\end{abstract}

\section{Keywords}

Ethnicity, Government, Education, Schools, University, Kenya

\section{Introduction}

Ethnicity can be defined as belonging to a social group that has common socio-cultural values like culture, religion and languages. A tribe is group of people within a geo-political region with common ancestry. Ethnicity is associated with culture, while tribe is related to common ancestors. In the context of this paper ethnicity and tribalism will be used interchangeably. Race is associated with biological origin of a particular group of people like African race, White/Caucasian race, Asian race, or Arab race. In Kenya, there are a total of 42 ethnic groups living in the 47 counties across the country. The country is made up of four main races that include the Africans, Asians, Whites and Arabs. Racism is not a pronounced phenomenon in Kenya like in the United States or in Europe. Many 
people in Kenya have grown up seeing fellow Africans and since majority lack exposure to other countries where racism is visibly present; racism is not pronounced in the country. Instead, ethnicity has taken the role of racism in Kenya in terms of discrimination in many places e.g. in employment, provision of services in public office and admission to schools and universities. There is regional and ethnic imbalance in representations in the universities in the number of students admitted to public universities, employment and leadership positions in the public universities, and the number of public universities and constituent colleges located in specific regions in terms of ethnic groups occupying those areas (Mwiria, 2006). This paper sheds lights on the issue of ethnicity in Kenyan universities and the different approaches in which the government has endeavored to tackle the problem. The article discusses the causes of ethnicity in Kenyan universities and also examines different approaches to curbing this problem. The article recommends a multi-facetted approach to tackling the issue of ethnicity which affects universities and in turn the entire education system, since universities serve humanity in Kenya and internationally.

\section{Ethnicity in Kenya Universities}

\subsection{Introduction}

In this section, the issue of ethnicity in Kenya is illuminated in terms of the historical perspective and how the colonial government perpetuated divisions among the indigenous groups in Kenya. Other pertinent issues discussed include; students' admission, employment of staff, composition of the university councils, appointment of Vice Chancellors and Chairs of university councils, and location of universities and constituent colleges in various counties in the country.

\subsection{Historical Background of Ethnicity in Kenyan}

Historically, Kenya was colonized by Britain until 1963 when independence was attained. Before independence Kenya was divided into ethnic groups by the colonial government. The main reason for this division was "divide and rule" policy adopted by the British colonial government to be able to control the rebellious indigenous groups. The British settlers were more interested in the areas that were economically viable, especially in agriculture. Therefore, they concentrated their efforts in developing those areas they got economic returns. These areas included the Rift Valley, Central Kenya and some parts of Western Region of Kenya. These are the areas that were exposed to the missionary activities before anywhere else. It therefore follows that the first institutions of learning including schools and universities were first established there. The University of Nairobi was the first to have been established in Nairobi which is considered to be predominantly inhibited by the Kikuyus. The ethnic groups that had first encounter with the British colonial government, the missionaries and the settlers tended to have more chances of higher education because schools and other learning institutions were set up there (KNBS, 2009). 


\subsection{Students' Admissions}

The current education system in Kenya tends to promote ethnicity through admission to high schools. The policy of admitting students to high schools follow system whereby the best students are admitted to national high schools from all counties, extra-county schools admit students from the region and county schools admit students from the county ${ }^{1}$. The national schools admit students from all over the country unlike the extra-county and county schools. This system promotes ethnicity in that there are less than 100 national schools in the whole country, which means most of the students are admitted in extra-county and county schools which are within their locality, limiting their chances of interacting with students from other parts of the country. There are negative ethnic/tribal stereo-types which have negative connotations against each tribe and if students do not have a chance of interacting with others from different tribes/ethnic groups then they might grow up believing in the biased information about other tribes which is passed from generation to generation. Students from different parts of the country are admitted to any public universities in the country not necessarily the one in their county. This promotes national cohesion and integration at the university level because students are able to interact with students from all parts of the country. These interactions at the university level sometimes even lead to ethnic intermarriages which is a good thing for the country, which is highly divided into tribal lines (MoEST, 2017).

From Table 1, the Kikuyu ethnic group with $17.7 \%$ of the total population has a $37.8 \%$ of the total number of students in the public universities and constituent colleges. The Kikuyu, Kamba, Luhya, and the Luo constitute $72.8 \%$ of the total number of students in the public universities and colleges while the remaining

Table 1. Ethnic composition of students in public universities in Kenya.

\begin{tabular}{ccccc}
\hline S/N & Ethnicity & Pop (2009) & Pop \% & Students' \% \\
\hline 1 & Kikuyu & $6,622,576$ & 17.7 & 37.8 \\
2 & Kamba & $3,893,157$ & 10.4 & 13 \\
3 & Luo & $4,044,440$ & 10.8 & 12 \\
4 & Luhya & $5,338,666$ & 14.2 & 10 \\
5 & Kalenjin & $4,967,328$ & 13.3 & 8 \\
6 & Meru & $1,658,108$ & 4.4 & 7 \\
7 & Kisii & $2,205,669$ & 5.9 & 4 \\
9 & Embu & 324,092 & 0.9 & 3 \\
10 & Others & 273,519 & 22.4 & 5.2 \\
& Total & $\mathbf{3 1 , 2 8 8 , 1 2 9}$ & $\mathbf{8 3 . 5}$ & 100 \\
\hline
\end{tabular}

Source: British Council (2006).

${ }^{1}$ Students are admitted to high school after sitting for the Kenya Certificate of Primary Education (KCPE) exams after 8 years of primary education. Students admitted in County and sub-county schools have fewer marks at KCPE than those admitted at national schools. Hence the notion that national schools are more prestigious and definitely take more students to the government sponsored public universities. 
Table 2. Ethnic composition of employees in public universities in Kenya.

\begin{tabular}{ccccccc}
\hline S/N & Ethnicity & $\begin{array}{c}\text { Pop } \\
(\mathbf{2 0 0 9 )}\end{array}$ & Pop \% & $\begin{array}{c}\text { No. of } \\
\text { Employees }\end{array}$ & Employment \% & $\begin{array}{c}\text { \% Pop Ratio \& } \\
\text { Employment }\end{array}$ \\
\hline 1 & Kikuyu & $6,622,576$ & 17.7 & 7050 & 23.6 & 5.9 \\
2 & Luo & $4,044,440$ & 10.8 & 4658 & 15.6 & 4.8 \\
3 & Kalenjin & $4,967,328$ & 13.3 & 4586 & 15.4 & 2.0 \\
4 & Luhya & $5,338,666$ & 14.2 & 4562 & 15.3 & 1.1 \\
5 & Kisii & $2,205,669$ & 5.9 & 2470 & 8.3 & 2.4 \\
6 & Kamba & $3,893,157$ & 10.4 & 2393 & 8.7 & -2.4 \\
7 & Meru & $1,658,108$ & 4.4 & 1348 & 4.5 & 0.1 \\
8 & Mijikenda & $1,960,574$ & 5.2 & 652 & 2.3 & -3.1 \\
9 & Embu & 324,092 & 0.9 & 419 & 1.4 & 0.5 \\
10 & Taita & 273,519 & 0.7 & 370 & 1.2 & 0.5 \\
& Total & $31,288,129$ & $\mathbf{8 3 . 5}$ & & 96.3 & \\
\hline
\end{tabular}

Source: NCIC (2016).

38 ethnic groups have only $27.2 \%$ to share amongst themselves. This is big misrepresentation of the minority ethnic groups which are majorly marginalized. This translates into employment in the public sector including in the public universities as shown in Table 2 in the next section which shows the Kikuyu having $23.6 \%$ of all employees in the public universities and constituent colleges (Mwiria, 2006).

\subsection{Employment in the Universities}

There is regional imbalance in terms of employment in the public universities and constituent colleges. According to the National Cohesion and Integration Commission (NCIC) Act of Kenya no public establishment should recruit more than one third of its staff members from one tribe.

From Table 2 it is clear the Kikuyu is the largest ethnic group in Kenya in terms of the proportion of the total population (17.7\%) but takes up $23.6 \%$ of all the jobs in the public universities and constituent colleges in Kenya. The Kikuyu, Luo, Luhya, Kalenjin, Kisii and Kamba make up $72.3 \%$ of the Kenyan population but constitute $86.9 \%$ of the total workforce in public universities and constituent colleges. This denies opportunities to enhance the face of Kenya in the public universities by excluding 36 other ethnic groups who reside within the country. Table 2 shows that the universities have in their workforce members from 10 ethnic groups in Kenya which take up $96.3 \%$ of the total workforce in the public universities and constituent colleges (NCIC, 2016: p. 124).

According to Table 3, by 2016, most Vice Chancellors and Principals were drawn from the dominant ethnic group within the location of the university/ college. One of the recommendations of the Ethnic and Diversity Audit of Public Universities and Constituent Colleges (2016) was recruitment of Vice Chancellors and Principals from ethnic communities that are not dominant in the loca- 
Table 3. Ethnic representation of vice chancellors and principals of public universities and constituent colleges in Kenya.

\begin{tabular}{cccc}
\hline S/N & Ethnic Group & Frequency & $\%$ \\
\hline 1 & Luo & 6 & 19.4 \\
2 & Kamba & 4 & 12.9 \\
3 & Kikuyu & 4 & 12.9 \\
4 & Luhya & 4 & 12.9 \\
5 & Meru & 4 & 12.9 \\
6 & Mijikenda & 3 & 9.7 \\
7 & Kalenjin & 2 & 6.5 \\
8 & Kisii & 2 & 6.5 \\
9 & Somali & 1 & 3.2 \\
10 & Teso & 1 & 3.2 \\
& Total & 31 & 100 \\
\hline
\end{tabular}

Source: NCIC (2016).

tion of the institution and should give priority to the marginalized groups. (NCIC, 2016: p. 25).

According to Section 7(2) of the NCIC Act of Kenya, no public establishment should recruit more than one third of its employees from one ethnic group. Table 4 shows a study carried out in 2016 by the National Cohesion and Integration Commission (NCIC) where only Six (6) out of the thirty one (31) Public Universities and constituent colleges complied with the above provision. The universities that complied are; Multimedia University of Kenya, Technical University of Kenya, Egerton University, University of Nairobi, The Cooperative University of Kenya and Moi University. The 2016 study, entitled "Ethnic and Diversity Audit of Public Universities and Constituent Colleges", carried out by NCIC in 31 public universities and constituent university colleges on employees and their ethnic affiliation, revealed ethnic imbalance in employment. Table 4 also indicates that where the Vice Chancellor or Principal is from a certain tribe and he/she is appointed in a university within his/her own locality, then majority of the employees are recruited from his/her tribe. In universities where the Vice Chancellor or Principal is from a different tribe other than the one in the locality, then again the majority of the employees are from the local community or tribe (NCIC, 2016: p. 25).

\subsection{Academic Ethnicity}

The academic departments and other sections in the public universities and constituent colleges have not been spared of ethnicity as well. It is common to find in some departments the members of both the academic staff and the non-teaching staff belonging to the same ethnic community. In some of the public universities and constituent colleges, you may find that the Vice Chancellor or Principal is from the local community and they influence the university 
Table 4. Ethnic representation of vice chancellors/principals and majority ethnic group among staff members of public universities and constituent colleges in Kenya.

\begin{tabular}{|c|c|c|c|c|c|}
\hline $\mathrm{S} / \mathrm{N}$ & University & $\begin{array}{l}\text { Ethnicity of the } \\
\text { VC/Principal }\end{array}$ & $\begin{array}{c}\text { Majority Ethnic } \\
\text { group (Staff) }\end{array}$ & $\begin{array}{c}\% \text { of } \\
\text { the staff }\end{array}$ & Compliance \\
\hline 1 & Kirinyaga University & Kikuyu & Kikuyu & 82.7 & Contravenes \\
\hline 2 & Kibabii University & Teso & Luhya & 79 & Contravenes \\
\hline 3 & Murang'a University & Kisii & Kikuyu & 76.1 & Contravenes \\
\hline 4 & Jaramogi Oginga Odinga University & Luo & Luo & 75.1 & Contravenes \\
\hline 5 & Rongo University & Luo & Luo & 72.5 & Contravenes \\
\hline 6 & Kisii University & Kisii & Kisii & 72.1 & Contravenes \\
\hline 7 & Meru University & Meru & Meru & 70.9 & Contravenes \\
\hline 8 & Dedan Kimathi University & Kikuyu & Kikuyu & 70.1 & Contravenes \\
\hline 9 & Masinde Muliro University & Luo & Luhya & 69.9 & Contravenes \\
\hline 10 & University of Kabianga & Kalenjin & Kalenjin & 68.8 & Contravenes \\
\hline 11 & Machakos University & Kamba & Kamba & 67.4 & Contravenes \\
\hline 12 & Maseno University & Luo & Luo & 63.4 & Contravenes \\
\hline 13 & Karatina University & Kikuyu & Kikuyu & 61.8 & Contravenes \\
\hline 14 & Moi University & Kalenjin & Kalenjin & 60.6 & Contravenes \\
\hline 15 & South Eastern Kenya University & Kamba & Kamba & 57.5 & Contravenes \\
\hline 16 & Chuka University & Meru & Meru & 53.1 & Contravenes \\
\hline 17 & University of Eldoret & Luhya & Kalenjin & 51.5 & Contravenes \\
\hline 18 & Garissa University College & Somali & Somali & 51.4 & Contravenes \\
\hline 19 & Jomo Kenyatta University & Luhya & Kikuyu & 45.3 & Contravenes \\
\hline 20 & Kenyatta University & Kikuyu & Kikuyu & 39.8 & Contravenes \\
\hline 21 & Maasai Mara University & Luhya & Maasai & 38.8 & Contravenes \\
\hline 22 & Taita Taveta University & Mijikenda & Taita & 38 & Contravenes \\
\hline 23 & Laikipia University & Kamba & Kikuyu & 37.6 & Contravenes \\
\hline 24 & University of Embu & Meru & Embu & 37.2 & Contravenes \\
\hline 25 & Pwani University & Mijikenda & Mijikenda & 36.8 & Contravenes \\
\hline 26 & Technical University of Mombasa & Mijikenda & Mijikenda & 34.5 & Complies \\
\hline 27 & Cooperative University of Kenya & Luhya & Kikuyu & 33.1 & Complies \\
\hline 28 & University of Nairobi & Kamba & Kikuyu & 30.1 & Complies \\
\hline 29 & Egerton University & Luhya & Kikuyu & 27.1 & Complies \\
\hline 30 & Technical University of Kenya & Luo & Kikuyu & 26.8 & Complies \\
\hline 31 & Multi-Media University & Meru & Kikuyu & 21.8 & Complies \\
\hline
\end{tabular}

Source: NCIC (2016).

council to appoint people from their community into positions of leadership in the institutions. In some public universities and constituent colleges, there is a possibility of a college, school or department having more academic and support staff coming from the same tribe because the head of that section belongs to the group. Sometimes, there is nepotism even when it comes to post-graduate students' supervision and graduation rate, where senior members of academic staff 
supervising students make sure students who are from their tribe graduate faster (Taaliu, 2011). The post-graduate students who come from "other tribes" may drop out or take more time to graduate because of frustration of supervisors who are not members of the students' ethnic group. When it comes to theses examination for post-graduate students, sometimes the panel members have to vote on whether the students has failed or passed and this voting often is done on ethnic lines. This means that faculty members who belong to the students' ethnic group will vote for the student to pass and hence marginalizing those who come from minority groups. The fact that the main tribes have more professors and senior staff in the academic departments and schools and also sitting in thesis examination panels will ensure that the students from those tribes will pass more often than those from the marginalized communities (Chapman, 2003).

\subsection{Ethnic Languages in Universities}

It is common to walk in the corridors and offices of some of the public universities and constituent colleges and find that language being used is not Kiswahili which is the national language nor is it English the official language but local language spoken in that region. Some of the office staff members will even ask clients what they need in the vernacular language of the region (CUE, 2017). Notwithstanding the fact that students in public universities and constituent colleges are admitted and drawn from all parts of the country. The lecturers are not spared as well. Some of the public universities have bulk of the lecturers coming from the county and it is not uncommon to hear them conversing in the local language with their colleagues and students (TSC, 2017).

\subsection{University Students and Ethnicity}

Students are admitted to any public universities or constituent colleges in Kenya not necessarily in their own counties. Every public university and constituent college has a Students' Government or Council, where students elect their own leaders who form a council to liaise with the university management in the administration of the institution. The students' councils which include the presidents or the chairpersons are elected by bone fide students of that university or college. Sometimes students will elect their leaders based on tribal/ethnic basis. A student will for instance vote in a chair of the student council because he or she comes from the same area or region, or they speak the same language. Sometimes students will vote on political party affiliation lines. The political parties in Kenya have tribal affiliations. The tribal affiliations mean that if a leader of a political party is a Kikuyu, the party will be predominantly be a Kikuyu party or a party of Mt Kenya region. These party affiliations are brought to universities through influence of the political leaders. In many public universities and constituent colleges there are tribal students' associations, for instance you may find the Luo or Luhya Students' Association. These tribal associations were common during the one party rule of the former President Daniel Moi. It is also common to find students associating themselves with other students who are from their 
tribes and even ending up getting married from the same community. Instead of university students having friends from other ethnic groups they tend to associate with the students from their tribes or those they went to school with. When walking in the corridors of some of the public universities or constituent colleges you will hear all kinds of languages being spoken in the campuses instead of Kiswahili or English.

\subsection{University Lecturers and Ethnicity}

Lecturers in public universities in Kenya are recruited by the individual university's councils. The Commission for University Education (CUE) is mandated by law to regulate higher education in Kenya and has outlined the criteria for qualification for each category of the faculty in both public and private universities. Every year when there is general election in Kenya tensions and sometimes fighting and tension has erupted between ethnic groups emanating from election disputes. This was witnessed in 2007/2008 post-election violence (PEV) that left over 1300 people dead in various parts of the country. ${ }^{2}$ In the violence that occurred, the public universities were not spared in terms of students and staff members. The main contest was on the presidential results between Mr. Mwai Kibaki (Kikuyu) and the opposition leader Mr. Raila Odinga (Luo). Mr. Raila was supported by Mr. William Ruto (Kalenjin) and Mr. Kibaki had Mr. Uhuru Kenyatta (Kikuyu) as his supporter. In some instances, the Kikuyu lecturers who were teaching in universities located in Luo or Kalenjin land and vice versa feared for their lives. Some had their homes torched and others even lost their lives and property. In fear of their lives, many sought employment in universities which were in their locality where they felt safe. Today, in the public universities, faculty members from one ethnic group are found to be more in a university which is located in their county. One of the reasons attributed to this is the fact that the lecturers feel safer working in "their" university than if they were working in a "foreign" university located in another county. The situation is made worse by the fact that the Vice Chancellors in some of the public universities and constituent colleges are drawn from the local community. It is not surprising therefore; in 2016 the political leaders in Uasin Gishu County were demonstrating against the newly appointed acting Vice Chancellor of Moi University whom they were accusing of not being from their tribe. The political leaders wanted the Cabinet Secretary to appoint a Kalenjin as Vice Chancellor from among the top Kalenjin professors in the university (TI-K, 2015).

\subsection{University Councils}

The university councils are appointed and constituted by the Cabinet Secretary (CS) for Education. Each university council has two representatives from the Government, one from the Ministry of Education and another from the Ministry

${ }^{2}$ During the 2007/2008 post-election violence, PEV many people fled where they had been settled for many years, if they did not belong to that community. Some had even intermarried with the local tribes, but during the violence there were cases of divorce. Husband and wives and children separated because they did not belong to the same tribe. 
Table 5. Ethnic representation of council members of public universities and constituent colleges in Kenya.

\begin{tabular}{cccc}
\hline S/N & Ethnic Group & Frequency & Percentage \\
\hline 1 & Kikuyu & 25 & 14.3 \\
2 & Kalenjin & 24 & 13.7 \\
3 & Luo & 20 & 11.4 \\
4 & Luhya & 17 & 9.7 \\
5 & Kamba & 13 & 7.4 \\
6 & Somali & 11 & 6.3 \\
7 & Mijikenda & 11 & 6.3 \\
8 & Meru & 11 & 6.3 \\
9 & Taita & 7 & 4 \\
10 & Kisii & 6 & 3.4 \\
11 & Embu & 6 & 3.4 \\
12 & Maasai & 5 & 2.9 \\
13 & Teso & 3 & 1.7 \\
14 & Swahili & 3 & 1.7 \\
15 & Asians & 2 & 1.1 \\
16 & Samburu & 2 & 1.1 \\
& Total & 168 & 100 \\
\hline
\end{tabular}

Source: NCIC (2016).

of Finance. The other members of the university council are appointed by the CS. The Vice Chancellor is an ex-official member of the university council by the virtue of being the Chief Executive Officer (CEO) of the university. The university councils ideally are composed of nine (9) members, which include the Vice Chancellor. The university councils are charged with the responsibility of the general governance of the university. The role of the day-to-day running of the university is left to the CEO of the university, the Vice Chancellor (CUE, 2017).

From Table 5 it is evident that $50 \%$ of the council members and their chairpersons come from the top four largest communities, namely; the Kikuyu, the Kalenjin, the Luhya, and the Luo. This leaves the other $50 \%$ to be shared by the 38 of the rest of the ethnic groups within the country. It is worth noting that those communities which were exposed to the missionaries first had their children going to school. This means these communities have more eligible members appointed as council members, hence the dominance of the more educated tribes in the university councils. ${ }^{3}$

\subsection{Geographical Location of Public Universities}

According to the Constitution of Kenya (2010) education including higher edu-

${ }^{3}$ The Cabinet Secretary for Education in Kenya has instituted changes (2017) in the appointment of university council chairpersons, whereby all of them are $\mathrm{PhD}$ holders and do not come from the local community. 
cation is mainly the responsibility of the National Government not the County Governments. Devolution is covered under Chapter 11 of the Kenya Constitution and the powers and functions of the two levels of Government are clearly spelt out in the Fourth Schedule. The Universities Act (2012) places the responsibility of management of higher education to the Commission for University Education (CUE). The Commission ensures the establishment of public universities and constituent colleges in each of the Counties, giving priority to Counties that do not have universities (Constitution of Kenya, 2010: p. 174).

The coding of the counties was done starting from the coastal region of Mombasa to upcountry. Therefore, Mombasa was given county number 001 and Nairobi 047 as shown in Table 6. It is worth noting that apart from Nairobi County, which is the capital city of the country, all the counties are ethnically based. This means that if you examine composition of each and every county in Kenya, the residents therein share a common history, race, religion, language or dialect, physical appearance, political affiliation and culture. The location of universities and constituent colleges in Kenya, is mostly politically motivated. This means the government of the day will locate a university or a constituent college in particular region for political gain. In most cases, the counties inhibited by the ethnic group/tribe which supports that government are rewarded with a public university or a constituent colleges being located there. If a county is regarded as an opposition zone to the government in power, then a public university might be denied. In some instances, the ethnic group might be an opposition county and therefore be rewarded or promised a public university if they support the current regime in general elections. The rationale behind this reward is that there are real or imagined benefits of having a public university or a constituent colleges within a county and "it is our time to eat syndrome, whereby the leaders of the day want to reward their people when in power". Some of these benefits include, employment of the local people in the university, local entrepreneurs can benefit by doing business with the university, students from the county can benefit by attending the local university whereby they can save on going to universities in far areas in terms of transportation, food and accommodation (they can commute from their homes).

Out of the 47 counties, 20 have a public university or a constituent college and 17 do not have a single one located there. Nairobi alone has 5 major public universities namely, University of Nairobi, Kenyatta University, Multimedia University of Kenya, the Cooperative University of Kenya, and Technical University of Kenya. Not to mention that Jomo Kenyatta University of Science and Technology though in Kiambu County is less than 10 kilometers away from Kenyatta University.

Some of the counties do not have a public university or a constituent college like Wajir, Mandera, Marsabit, Isiolo, Lamu, and Tana River. These counties are located in the arid areas which were originally marginalized by the colonial government because of lack of resources to exploit from there. The British colonial government concentrated on developing those areas that they considered eco- 
Table 6. Distribution of universities in the 47 counties in Kenya.

\begin{tabular}{|c|c|c|c|}
\hline$S / N$ & County & No. of Univ. & Universities \\
\hline 1 & Mombasa & 1 & Technical University of Mombasa \\
\hline 2 & Kwale & N/A & $\mathrm{N} / \mathrm{A}$ \\
\hline 3 & Kilifi & 1 & Pwani University \\
\hline 4 & Tana River & N/A & N/A \\
\hline 5 & Lamu & $\mathrm{N} / \mathrm{A}$ & N/A \\
\hline 6 & Taita Taveta & 1 & Taita Taveta University College \\
\hline 7 & Garissa & 1 & Garissa University College \\
\hline 8 & Wajir & N/A & N/A \\
\hline 9 & Mandera & N/A & $\mathrm{N} / \mathrm{A}$ \\
\hline 10 & Marsabit & N/A & N/A \\
\hline 11 & Isiolo & N/A & N/A \\
\hline 12 & Meru & 1 & Meru University of Science and Technology \\
\hline 13 & Tharaka Nithi & 1 & Chuka University \\
\hline 14 & Embu & 1 & University of Embu \\
\hline 15 & Kitui & 1 & South Eastern Kenya University \\
\hline 16 & Machakos & 1 & Machakos University \\
\hline 17 & Makueni & N/A & $\mathrm{N} / \mathrm{A}$ \\
\hline 18 & Nyandarua & N/A & $\mathrm{N} / \mathrm{A}$ \\
\hline 19 & Nyeri & 2 & Karatina University, Dedan Kimathi University of Technology \\
\hline 20 & Kirinyaga & 1 & Kirinyaga University of Science and Technology \\
\hline 21 & Murang'a & 1 & Murang'a University of Science and Technology \\
\hline 22 & Kiambu & 1 & Gatundu University College, Jomo Kenyatta University of Science and Technology \\
\hline 23 & Turkana & 1 & Turkana University College \\
\hline 24 & West Pokot & N/A & $\mathrm{N} / \mathrm{A}$ \\
\hline 25 & Samburu & N/A & N/A \\
\hline 26 & Trans Nzoia & N/A & N/A \\
\hline 27 & Uasin Gishu & 2 & Moi University, University of Eldoret \\
\hline 28 & Elgeyo Marakwet & N/A & $\mathrm{N} / \mathrm{A}$ \\
\hline 29 & Nandi & 1 & Koitalel Samoei University College \\
\hline 30 & Baringo & N/A & N/A \\
\hline 31 & Laikipia & 1 & Laikipia University \\
\hline 32 & Nakuru & 1 & Egerton University \\
\hline 33 & Narok & 1 & Maasai Mara University \\
\hline 34 & Kajiado & N/A & $\mathrm{N} / \mathrm{A}$ \\
\hline 35 & Kericho & 1 & University of Kabianga \\
\hline 36 & Bomet & 1 & Bomet University College \\
\hline 37 & Kakamega & 1 & Masinde Muliro University of Science and Technology \\
\hline
\end{tabular}




\section{Continued}

\begin{tabular}{|c|c|c|c|}
\hline 38 & Vihiga & 1 & Kaimosi University College \\
\hline 39 & Bungoma & 1 & Kibabii University \\
\hline 41 & Siaya & $\mathrm{N} / \mathrm{A}$ & $\mathrm{N} / \mathrm{A}$ \\
\hline 42 & Kisumu & 3 & Jaramogi Oginga Odinga University of Science and Technology, Maseno University \\
\hline 43 & Homa Bay & 1 & Tom Mboya University College \\
\hline 44 & Migori & 1 & Rongo University \\
\hline 45 & Kisii & 1 & Kisii University \\
\hline 46 & Nyamira & $\mathrm{N} / \mathrm{A}$ & $\mathrm{N} / \mathrm{A}$ \\
\hline 47 & TOTAL & 38 & \\
\hline
\end{tabular}

Source: NCIC (2016).

nomically viable in terms of agriculture. This development includes setting up of schools and other institutions of learning, infrastructural development and appointment/employment in top government positions. This trend of marginalization was entrenched further by the independence governments which were led by African presidents (all the four presidents in Kenya since independence have rotated from within the two majority ethnic groups Kikuyus and the Kalenjins, because even voting in general elections is done on ethnic lines).

\section{Conclusion}

The issue of ethnicity in Kenya affects all sections of the universities and constituent colleges. It ranges from admission of students to universities, employment of both teaching and non-teaching staff, appointment of Vice Chancellors and Principals and university council members. Since independence in 1963, the various regimes seem to be lacking commitment and good will to fight the deep seated ethnicity in the universities and constituent colleges in the country. In 2016/2017 period the Cabinet Secretary for Education Dr. Fred Matiang'i instituted reforms in the higher institutions of learning. He particularly put up measures to curb ethnicity in the universities. Some of these measures include appointing Vice Chancellors and Principals and council chairpersons of public universities from communities out of where the universities are geographically located. The National Cohesion and Integration Commission (NCIC) has done much to make sure that universities adhere to the policy of not recruiting more than a third of the total workforce from one tribe, but much more need to be done. The commission has also introduced a policy where universities are supposed to integrate the teaching of national unity and cohesion in their curricula. From the Kenyan context further research need to be done internationally. More research can be done internationally to corroborate the peculiarity of ethnicity and racism in universities in other countries for comparative purposes. 


\section{References}

Commission for University Education (CUE) (2017). Academic Staff Qualifications. http://www.cue.or.ke/

Constitution of Kenya (2010). The Fourth Schedule. https://www.kenyaembassy.com/pdfs/the\%20constitution\%20of\%20kenya.pdf

Kenya National Bureau of Statistics (KNBS) (2009). Census. https://www.knbs.or.ke/

Ministry of Education, Science and Technology (MOEST) (2017). Access to Education. http://www.education.go.ke/index.php/online-services/form-one-selection

Mwiria, K. M. (2006). Public \& Private Universities in Kenya. New Challenges, Issues \& Achievements. Nairobi: East African Educational Publishers.

National Cohesion and Integration Commission (NCIC) (2016). Publication No. 3/2016.

Taaliu, S. T. (2011). Perspectives on the Teaching Profession in Kenya: Perception, Status, and Job (Dis) Satisfaction. Germany: Lambert Academic Publishers.

Teachers Service Commission (TSC) (2017). https://www.tsc.go.ke

Transparency International Kenya (TI-K) (2015). Promoting Integrity in Schools. http://www.tikenya.org/

\section{Submit or recommend next manuscript to SCIRP and we will provide best} service for you:

Accepting pre-submission inquiries through Email, Facebook, LinkedIn, Twitter, etc. A wide selection of journals (inclusive of 9 subjects, more than 200 journals) Providing 24-hour high-quality service User-friendly online submission system Fair and swift peer-review system Efficient typesetting and proofreading procedure Display of the result of downloads and visits, as well as the number of cited articles Maximum dissemination of your research work

Submit your manuscript at: http://papersubmission.scirp.org/

Or contact ojl@scirp.org 